\title{
PENGGUNAAN MODEL INKUIRI UNTUK MENINGKATKAN KEMAMPUAN BERPIKIR KRITIS SISWA DALAM PEMBELAJARAN IPS DI SD
}

(Penelitian Tindakan Kelas di Terapkan di Kelas III SD Cibiru IX Kecamatan Cileunyi Kabupaten Bandung)

\author{
Tin Rustini ${ }^{1}$ \\ Farida Tjandra
}

\begin{abstract}
ABSTRAK
Pembelajaran di sekolah cenderung sangat teoritis dan terkait dengan kehidupan yang ada lingkungan nyata. Rumusan masalah, bagaimana meningkatkan kemampuan berpikir kritis siswa dengan menggunakan model Inkuiri dan bagaimana hasil belajar IPS dengan menggunakan Model Inkuiri. Proses penerapan model dalam pembelajaran ini berfokus kepada Penelitian Tindakan Kelas( PTK), model Kemmis dan McTaggart yang terdiri dari empat komponen, yaitu (1). Perencanaan (planning), (2). Tindakan (action) (3). Observasi (observation), dan (4). Refleksi (reflection). Peneltian tindakan ini dilakukan dalam tiga siklus, di mana setiap siklus materi dan tujuan pembelajaran yang berbeda. Hasil dari penelitian ini menyimpulkan bahwa model inkuri terbimbing merupakan salah satu model pembelajaran yang dapat mengembangkan kemampuan berpikir kritis siswa, sehingga proses dan hasil belajar siswa akan lebih baik. Pada akhir peneliti ini merekomendasikan bahwa untuk merangsang timbulnya masalah-masalah dari siswa, guru harus memikirkan suatu kegiatan eksplorasi yang akan dilakukan oleh siswa, agar siswa mempunyai gagasan untuk mengemukakan pendapat dan mengajukan pertanyaan terhadap materi yang diajarkan, menumbuhkan keberanian seluruh siswa dalam menggunggkapkan masalah, guru harus memberikan penguatan kepada siswa yang bertanya sehingga siswa lainnya termotivasi untuk bertanya.
\end{abstract}

\section{Kata kunci: Berpikir Kritis,Model Inkuiri, Pembelajaran IPS.}

\section{A. PENDAHULUAN}

Pendidikan IPS memegang peranan penting dalam upaya mewujudkan tujuan pendidikan nasional. Hal ini karena mengembangkan potensi peserta didik menjadi manusia yang berakhlak mulia, sehat, berilmu, cakap, kreatif, mandiri, dan menjadi warga negara yang demokratis serta bertanggung jawab, sebagaimana yang menjadi tujuan pendidikan nasional, juga merupakan tujuan pendidikan IPS.

Fungsi mata pelajaran IPS di SD adalah untuk mengembangkan sikap rasional tentang gejala-gejala sosial, serta wawasan tentang perkembangan masyarakat Indonesia dan masa lampau serta masa kini. Sedangkan menurut Somatri (2001:199)," tujuan pendidikan IPS adalah untuk membantu tumbuhnya

\footnotetext{
${ }^{1}$ Dosen PGSD UPI Kampus Cibiru
} 
berpikir ilmuwan sosial dan memahami konsep-konsepnya, serta membantu tumbuhnya warga Negara yang baik.”

Berpikir kritis adalah suatu kegiatan melalui cara berpikir tentang ide atau gagasan yang berhubungan dengan konsep yang diberikan atau masalah yang dipaparkan. Seperti yang dikemukakan oleh Sutisyana (1996:23) bahwa 'berpikir krtitis yang dimaksud kegiatan menganalisis ide atau gagasan kearah yang lebih spesifik, membedakan seacara tajam, memilih, mengeidentifikasi, mengkaji dan mengembangkan kearah yang lebih sempurna'.

Salah satu strategi pembelajaran yang membantu guru untuk mengaitkan salah satu konsep pembelajaran dengan dunia nyata adalah model Inkuiri. Model Inkuiri diawali dengan pengamatan untuk memahami konsep dan dilanjutkan dengan melaksanakan kegiatan yang bermakna untuk menghasilkan rumusan. Dengan mengembangkan kebiasaan pola berpikir kritis, langkah atau tahapannya dimulai dari perumusan masalah, pengumpulan data dengan obsever, menganalisa dan menarik kesimpulan (Suarma. 2007:436). Dengan demikian siswa akan terdorong untuk menghubungkan antara pengetahuan yang dimilikinya dengan penerapan kehidupan sehari-hari yang ada didalamnya.

Menurut Tobing (Suryani, 2008:2),' model Inkuiri merupakan salah satu alternatif kegiatan pembelajaran yang melibatkan siswa untuk menemukan konsep secara mandiri. Dalam model Inkuiri siswa dilatih sebagai seorang ilmuwan, yaitu: melakukan proses ilmiah untuk mendapatkan konsep dan siswa dilatih menggunakan daya nalarnya untuk memecahkan suatu masalah melaui observasi pengalamannya di gunakan sebagai sumber belajar yang ada di lingkungan serta mengaitkan materi yang di ajarkan dengan permasalahan dalam kehidupan seharihari. Masalah yang di sajikan pada siswa merupakan masalah kehidupan seharihari (kontekstual) yang solusinya tidak mutlak mempunyai satu jawaban yang benar, artinya siswa di tuntut untuk belajar kreatif, menjadi individual yang mempunyai wawasan yang luas serta mampu melibatkan hubungan pelajaran dengan aspek-aspek yang ada di lingkungannya'.

Pembelajaran IPS yang peneliti amati di SD kurang menarik perhatian bagi siswa, karena guru hanya menggunakan metode ceramah pada saat mengajar, di samping itu guru juga kurang menggali pengetahuan yang ada pada diri siswa, dan mengembangkan kemampuan berpikir kritis, sedangkan guru di hadapkan pada tuntutan kemampuan mempertanggungjawabkan dalam mengembangkan perangkat pembelajaran yang lebih baik. Guru harus berusaha sebagai fasilitator bagi siswa, agar dapat menumbuh kembangkan kemampuan para siswa dalam menggali informasi yang dibutuhkannya, sehingga siswa dapat merumuskan sesuatu yang dapat di jadikan solusi untuk suatu masalah yang sedang dihadapinya.

Peneliti mengambil model Inkuiri, karena menurut peneliti model Inkuiri cocok untuk di gunakan pada kelas III SD, karena model Inkuiri ini guru melatih siswa agar lebih aktif dalam kegiatan pembelajaran yang menekankan pada proses berpikir secara kritis dan analitis untuk mencari dan menemukan sendiri jawaban dari suatu masalah yang di pertanyakan.

Berdasarkan latar belakang masalah yang telah di uraikan di atas, maka permasalahan umum dalam penelitian adalah: Bagaimana meningkatkan 
kemampuan berpikir kritis siswa dalam proses pembelajaran IPS SD dengan menggunakan model inkuiri di kelas III SD cibiru IX?Adapun yang menjadi sub masalah dalam penelitian ini adalah:

1. Bagaimana meningkatkan kemampuan berpikir kritis siswa dengan menggunakan model Inkuiri dalam pembelajaran IPS di SD?

2. Bagaimana hasil belajar IPS dengan menggunakan model Inkuiri dalam pembelajaran IPS di SD?

Tujuan penelitian ini secara umum adalah: Untuk mengetahui gambaran tentang model inkuiri agar dapat meningkatkan kemampuan berpikir kritis siswa dalam proses pembelajaran IPS di kelas III SD. Sedangkan secara khusus penelitian ini bertujuan sebagai berikut:

1. Mendeskripsikan kemampuan berpikir kritis siswa dengan menggunakan model Inkuiri dalam pembelajaran IPS di SD?

2. Mendeskripsikan hasil belajar IPS dengan menggunakan model Inkuiri dalam pembelajaran IPS di SD?

\section{B. TINJAUAN TEORITIS}

\section{Model Pembelajaran Inkuiri}

Inkuiri berasal dari kata toinquireyang berarti ikut serta, atau terlibat, dalam mengajukan pertanyaan-pertanyaan, mencari informasi, dan melakukan penyelidikan. Ia menambahkan bahwa pembelajaran inkuiri ini bertujuan untuk memberikan cara bagi siswa untuk membangun kecakapan-kecakapan intelektual (kecakapan berpikir) terkait dengan proses-proses berpikir reflektif. Jika berpikir menjadi tujuan utama dari pendidikan, maka harus ditemukan cara-cara untuk membantu individu untuk membangun kemampuan itu.

Model Inkuiri didefinisikan oleh Piaget (Sund dan Trowbridge, 1973) sebagai berikut: 'Pembelajaran yang mempersiapkan situasi bagi anak untuk melakukan eksperimen sendiri; dalam arti luas ingin melihat apa yang terjadi, ingin melakukan sesuatu, ingin menggunakan simbul-simbul dan mencari jawaban atas pertanyaan sendiri, menghubungkan penemuan yang satu dengan penemuan yang lain, membandingkan apa yang ditemukan dengan yang ditemukan orang lain'.

Pembelajaran Inkuiri menekankan kepada proses mencari dan menemukan. Materi pelajaran tidak diberikan secara langsung. Peran siswa dalam pembelajaran ini adalah mencari dan menemukan sendiri materi pelajaran, sedangkan guru berperan sebagai fasilitator dan pembimbing siswa untuk belajar. Pembelajaran inkuiri merupakan rangkaian kegiatan pembelajaran yang menekankan pada proses berpikir kritis dan analitis untuk mencari dan menemukan sendiri jawaban dari suatu masalah yang dipertanyakan. Proses berpikir itu sendiri biasanya dilakukan melalui tanya jawab antara guru dan siswa. Pembelajaran ini sering juga dinamakan pembelajaran heuristic, yang berasal dari bahasa Yunani, yaitu heuriskeinyang berarti "saya menemukan:

Salah satu nilai penting yang terkandung dalam model inkuri ialah nilai psikologis yang berupa pengembangan kepercayaan diri pada siswa untuk secara mandiri melakukan kegiatan intelektual menghadapi masalah. 
Model pembelajaran yang akan digunakan dalam penelitian ini adalah model pembelajaran Inkuiri terbimbing (Smaal Group Inkuiri) dengan tahapanya yaitu membina suasana yang responsif, mengemukakan permasalahan untuk inkuiri, pertanyaan-pertanyaan siswa, merumuskan hipotesis dan menguji hipotesis.

Hal yang perlu diperhatikan dalam penerapan langkah Inkuiri terbimbing adalah pertanyaan-pertanyaan yang diajukan harus terarah dan tidak menyimpang dari pokok permasalahan yang sedang dibahas dan benar-benar dapat merangsang siswa untuk dapat mengembangkan kemampuan berpikir kritisnya untuk menemukan konsep.

Jadi Model Inkuiri ini bertujuan untuk menolong siswa dalam mengembangkan disiplin intelektual dan keterampilan yang dibutuhkan serta mengajak siswa untuk aktif dalam memecahkan satu masalah. Penggunaan model inkuiri dalam pembelajaran Biologi besar manfaatnya dalam meningkatkan kualitas pembelajaran, karena dengan penggunaan model inkuiri dalam proses pembelajaran dapat mendorong siswa untuk berpikir dan bekerja atas inisiatifnya sendiri, bersifat objektif, jujur, dan terbuka, serta memberikan kesempatan kepada siswa untuk belajar sendiri dan dapat mengembangkan bakat dan kecakapan individunya. Dengan pelaksanaan model inkuiri diharapkan bagi siswa termotivasi dalam proses pembelajaran dan dapat meningkatkan hasil belajar yang maksimal.

\section{Konsep Berpikir Kritis}

Berpikir kritis adalah proses mental untuk menganalisis atau mengevaluasi informasi. Informasi tersebut dapat didapatkan dari hasil pengamatan, pengalaman, akal sehat atau komunikasi.

Menurut Halpen (1996), “berpikir kritis adalah memberdayakan keterampilan atau strategi kognitif dalam menentukan tujuan. Proses tersebut dilalui setelah menentukan tujuan, mempertimbangkan, dan mengacu langsung kepada sasaran-merupakan bentuk berpikir yang perlu dikembangkan dalam rangka memecahkan masalah, merumuskan kesimpulan, mengumpulkan berbagai kemungkinan, dan membuat keputusan ketika menggunakan semua keterampilan tersebut secara efektif dalam konteks dan tipe yang tepat. Berpikir kritis juga merupakan kegiatan mengevaluasi-mempertimbangkan kesimpulan yang akan diambil manakala menentukan beberapa faktor pendukung untuk membuat keputusan. Berpikir kritis juga biasa disebut directedthinking, sebab berpikir langsung kepada fokus yang akan dituju”.

Karakteristik Berpikir Kritis menurut Angelo (Arief Achmad, 2007), adalah analisis, sintesis, pengenalan masalah dan pemecahannya, kesimpulan, dan penilaian. Dalam proses pendidikan, khususnya dalam pembelajaran ilmu pengetahuan sosial merupakan sarana yang tepat dalam menumbuhkan kemampuan berpikir kritis siswa. Di dalam pembelajaran IPS, banyak konsep atau masalah sosial yang ada di lingkungan siswa dapat di jadikan suatu objek untuk dapat menumbuhkan cara berpikir kritis siswa. 


\section{METODOLOGI PENELITIAN}

Penelitian tindakan Kelas ini di laksanakan di Kelas III SD Cibiru IX kecamatan Cileunyi kabupaten Bandung. Pemilihan siswa kelas III SD Cibiru IX kecamatan Cileunyi kabupaten Bandung sebagai subjek penelitian dengan pertimbangan adanya sejumlah masalah yang di hadapi oleh guru sebagai peneliti yang berkaitan dengan pelaksanaan pembelajaran, mendapat dorongan dan dukungan dari pihak sekolah, baik dari pihak kepala sekolah maupun rekan-rekan kerja profesi yang ada di lingkungan SD Cibiru IX kecamatan Cileunyi Kabupaten Bandung serta tempatnya strategis, letaknya tidak jauh dari Universitas Pendidikan Indonesia Kampus Cibiru dan SD Cibiru IX mudah di jangkau dengan berjalan kaki saja.

Metode yang di gunakan dalam melakukan penelitian ini adalah metode kuantitatif dengan teknik penelitian tindakan kelas (actionresearch).Di sini peneliti menggunakan Penelitian Tindakan Kelas (PTK). Kemmis dan McTaggart (Iskandar, 2011:22-23).Desain Penelitian Tindakan Kelas yang digunakan dalam penelitian ini berbentuk spiral atau siklus menurutKemmis dan McTaggart (Trianto, 2011: 31) terdiri dari empat komponen yaitu: Perencanaan, Tindakan, Obsevasi, dan Refleksi. Berikut gambar desain penelitian menurut Kemis dan MC Taggart.

Berdasarkan instrumen yang direncanakan, pengumpulan datapun dilakukan melalui lembar observasi, lembar wawancara, lembar kerja siswa, catatan lapangan, dan kamera foto. Kegiatan tersebut dilakukan agar data yang di kumpul dapat terkumpul dan dapat di uraikan dalam bentuk deskripsi, kemudian dianalisis untuk refleksi, sehingga di peroleh suatu temuan baru berupa perubahan untuk tindakan selanjutnya.

Dalam penelitian tindakan kelas ini, analisis data yang di gunakan yaitu analisis data kuantitatif. Analisis data di lakukan setelah data terkumpul, dan data tersebut di saring dan di tarik kesimpulan. Pengumpulan data dan analisisnya di lakukan secara terus-menerus dari awal sampai dengan akhir proses pembelajaran yang dilakukan oleh peneliti di kelas.

\section{HASIL PENELITIAN DAN PEMBAHASAN}

Berdasarkan penelitian yang dilaksanakan, telah diperoleh berbagai temuantemuan yang akan dibahas pada uraian di bawah ini:

\section{Siklus I}

Kegiatan belajar siswa pada siklus I ini, guru melakukan pembelajaran selama dua tindakan. Dari setiap pembelajarannya guru menggunakan model Inkuiri dengan materi yang berbeda-beda.

Pembelajaran yang dilakukan disiklus I ini siswa masih cenderung malumalu untuk mengungkapkan ide maupun pendapatnya. Pada pembelajaran tahap merumuskan masalah, siswa terlihat tidak semangat belajar dan masih malu jika ditunjuk oleh guru untuk menjawab pertanyaan. Untuk tahap merumuskan hipotesis secara mandiri. Sedangkan tahap mencari informasi terjadi dalam diskusi kelompok. Alasan guru melakukan diskusi kelompok adalah untuk membiasakan siswa agar dapat berperan aktif, setidaknya selama berada di dalam kelompok. Aktif bertukar pendapat, aktif berpikir, dan aktif mencari informasi. 
Hal tersebut sesuai dengan pendapat Sagala(2003:208) yang mengemukakan bahwa” manfaat diskusi antara lain adalah diskusi dapat menumbuhkan partisipasi aktif kalangan peserta didik." Untuk tahap menganalisis data, siswa juga cenderung masih malu untuk melaporkan hasil diskusinya. Sedangkan untuk tahap menyimpulkan, siswa juga masih belum mampu menyimpulkan secara mandiri. Selain itu, nilai evaluasi dan nilai proses berpikir siswa juga masih rendah.

Pada siklus 1 tindakan nilai rata proses berpikir kritis masih rendah, Tentu saja semua itu tidak terlepas dari bimbingan guru yang terus berusaha melaksanakan upaya perbaikan pembelajaran. Guru terus memotivasi siswa agar percaya diri dan aktif selama pembelajaran. Ternyata semua itu memberikan dampak yang positif bagi perkembangan siswa. Berikut nilai rata-rata proses berpikir kritis siswa pada siklus 1

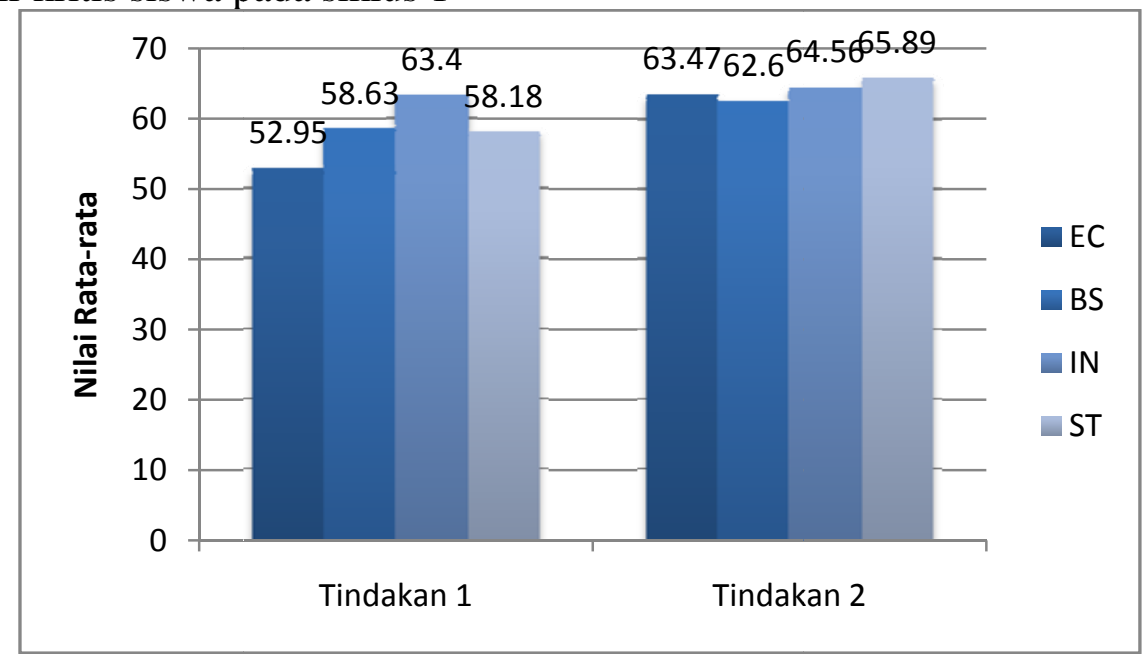

\section{Grafik 1}

Nilai rata-rata Proses Berpikir Kritis Siswa pada Siklus I

\section{Keterangan:}

ElementaryClarification $(\mathrm{EC})=$ Penjelasan sederhana

BasicSpport(BS) = Keterampilan dasar

Inference $(\mathrm{IN})=$ Menyimpulkan

Strategi andTactics $(\mathrm{ST})=$ Strategi dan taktik

Sedangkan nilai evaluasi siswa pada siklus I yang terdiri dari dua tindakan ini terus mengalami peningkatan. Meskipun masih dibawah nilai KKM (Kriteria Kentuntasan Minimal), nilai evaluasi terus mengalami peningkatan pada tindakan yang selanjutnya. Hal ini dapat dilihat pada grafik dibawah ini: 


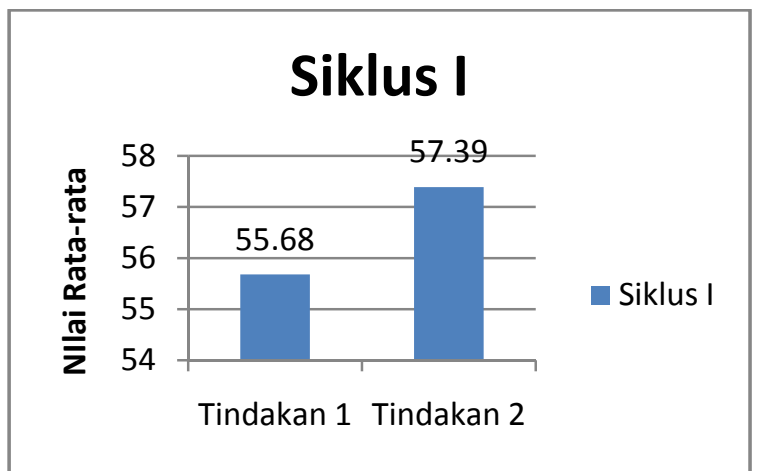

\section{Grafik 2}

\section{Siklus II}

\section{Nilai rata-rata Evaluasi Siswa pada Siklus I}

Pada saat pelaksanaan siklus II, guru melakukan pembelajaran sebanyak dua tindakan. Materi yang diajarkan pada siklus II ini adalah mengenai lingkungan alam dan buatan. Pembelajaran dilakukan sesuai dengan tahapan Inkuiri yaitu merumuskan masalah dalam bentuk pertanyaan, menyusun hipotesis, mengumpulkan data, menganalisa data, dan menarik kesimpulan. Tahap pembelajaran dengan menggunakan model inkuiri hampir sama dengan tahapan inkuiri yang di ungkapkan oleh Sanjaya (2008:202) yaitu” orientasi, merumuskan masalah, merumuskan hipotesis, mengumpulkan data, menguji hipotesis, merumuskan kesimpulan.

Dari temuan-temuan esensial yang didapatkan menunjukkan bahwa siswa sudah mulai memahami langkah-langkah Inkuiri yang pertama yaitu merumuskan masalah dalam bentuk pertanyaan yang berkaitan dengan materi ajar, siswa antusias untuk membuat pertanyaan-pertanyaan. Pada saat pembelajaran, guru memberikan satu pertanyaan yang bertujuan untuk memotivasi dan memancing siswa agar mampu merumuskan pertanyaan secara mandiri. Hal tersebut sangat berbeda dengan keadaan yang terjadi pada siklus I. peningkatan proses pembelajaran dapat terlihat pada tahap Inkuiri yang lainnya.

Selain itu, nilai proses berpikir kritis siswa mengalami peningkatan yang cukup bagus berikut grafik yang menunjukkan peningkatan proses berpikir kritis siswa. 


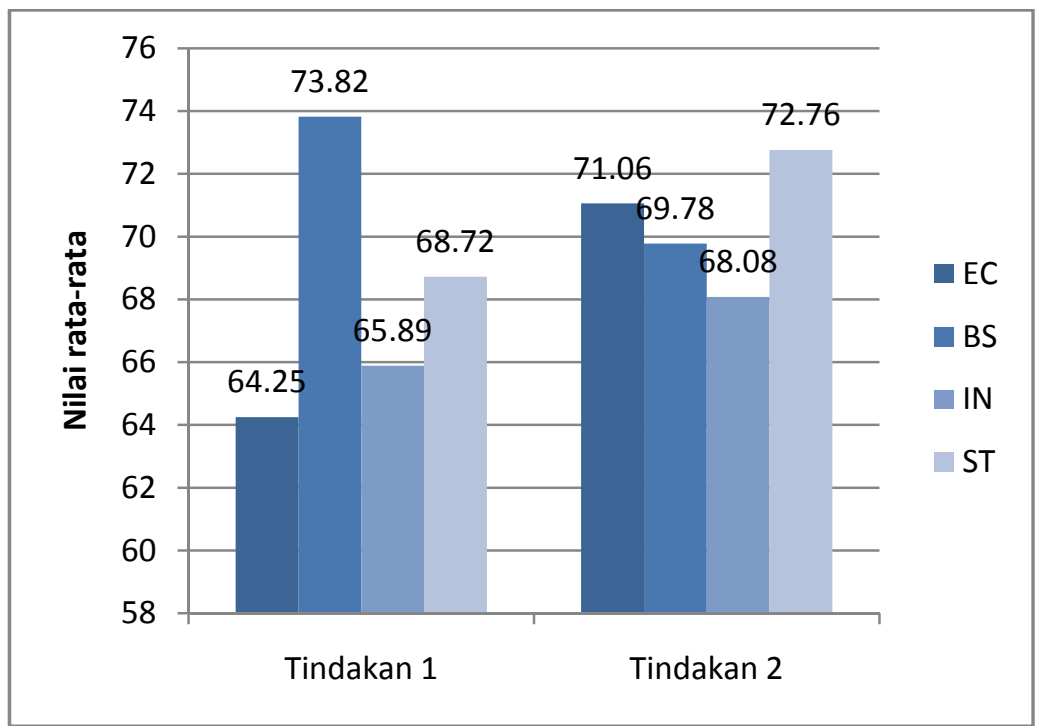

\section{Grafik 3}

Keterangan:

Nilai rata-rata Proses Berpikir Kritis Siswa pada Siklus II

ElementaryClarification $(\mathrm{EC})=$ Penjelasan sederhana

BasicSpport(BS) = Keterampilan dasar

Inference $(\mathrm{IN})=$ Menyimpulkan

Strategi andTactics $(\mathrm{ST})=$ Strategi dan taktik

Selain nilai rata-rata berpikir kritis siswa yang meningkat, nilai rata-rata hasil evaluasi pada siklus II pun meningkat, hal tersebut dapat dilihat pada grafik di bawah ini:

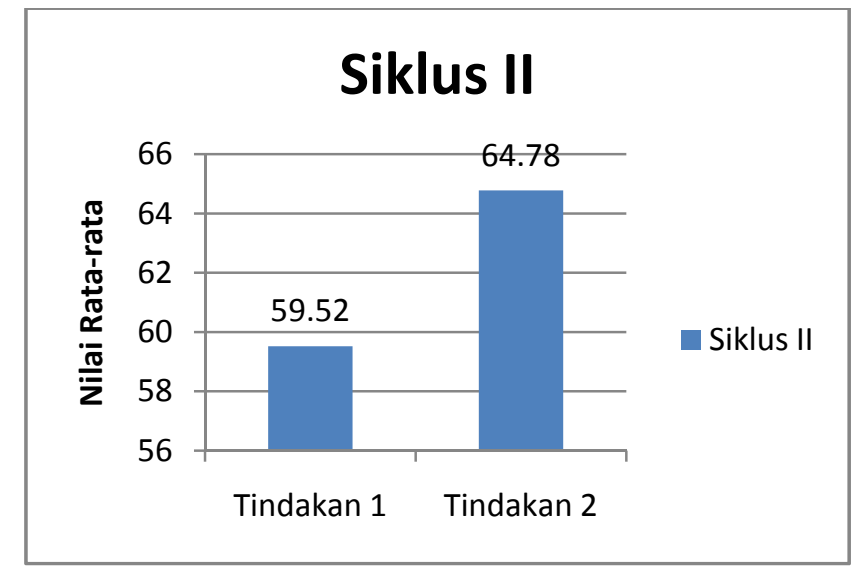

\section{Grafik 4}

Nilai rata-rata Evaluasi Siswa pada Siklus II

Nilai rata-rata evaluasi siswa dari tiap tindakan terus mengalami tindakan. Guru Mengambil keputusan bahwa peningkatan nilai rata-rata tersebut terjadi karena pembelajaran yang dilakukan bermakna bagi siswa.

\section{Siklus III}

Dari temuan pada siklus III, menggambarkan bahwa pada saat pelaksanaan siklus III siswa sudah lebih memahami langkah-langkah Inkuiri yang mereka lakukan selama belajar sehingga pada tahap Inkuiri yang pertama yaitu 
merumuskan masalah dalam bentuk pertanyaan yang berkaitan dengan materi ajar, siswa antusias untuk menuliskan pertanyaan. Pada saat pembelajaran, peran guru saat memberikan satu pertanyaan yang bertujuan untuk memotivasi dan memancing siswa agar mampu merumuskan pertanyaan secara mandiri sudah berkurang. Peningkatan proses pembelajaran lain juga terlihat pada tahap inkuiri yang lainnya. Misalnya pada saat tahap mengumpulkan informasi, siswa tetap berada dalam kelompok dan mereka benar-benar aktif dalam mencari informasi. Siswa jika terlihat tertib ketika mengikuti pelajaran di bandingkan pembelajaran sebelumnya. Selain peningkatan dalam hal proses pembelajaran, nilai evaluasi siswa juga mengalam peningkatan yang sangat drastis. Berikut grafik nilai ratarata proses berpikir kritis siswa.

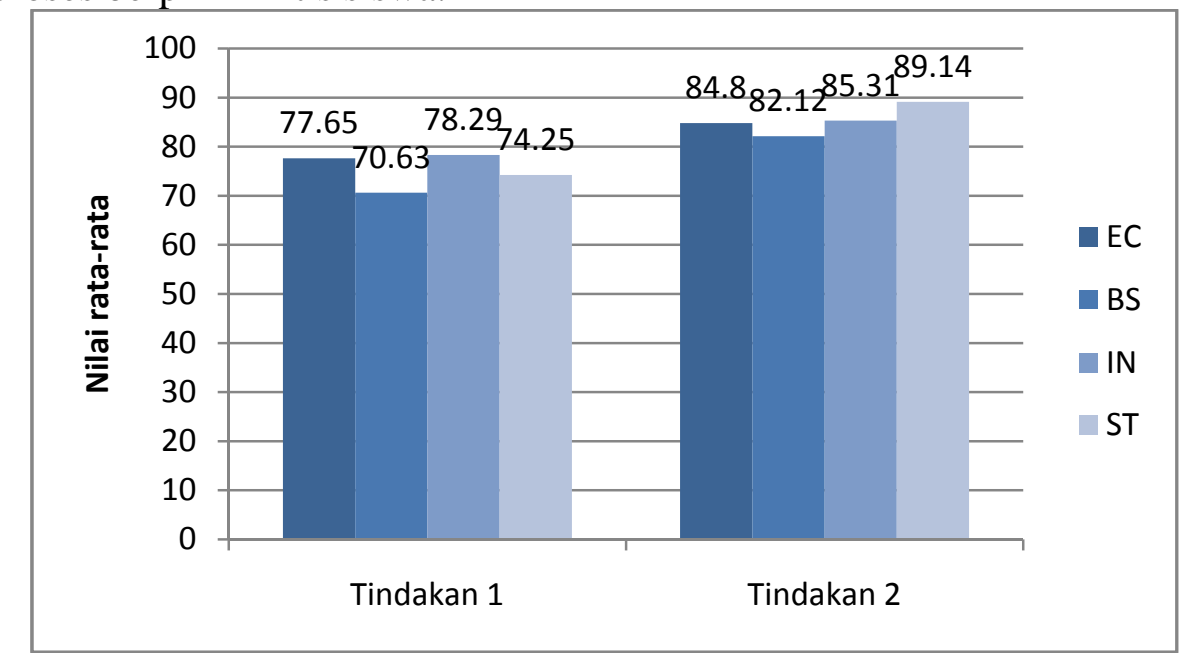

\section{Grafik 5}

Nilai rata-rata Proses Berpikir Kritis Siswa pada Siklus III

\section{Keterangan:}

ElementaryClarification $(\mathrm{EC})=$ Penjelasan sederhana

BasicSpport(BS) = Keterampilan dasar

Inference $(\mathrm{IN})=$ Menyimpulkan

Strategi andTactics $(\mathrm{ST})=$ Strategi dan taktik

Peningkatan nilai berpikir kritis siswa juga dialami oleh Alfiyah (2011) dan Meria Susana (2010) pada saat melakukan penelitian. Jika penelitian mengenai pendekatan Inkuiri yang dilakukan Alfiyah (2011) terbukti dapat meningkatkan hasil belajar siswa pada konsep energi bunyi, maka berbeda sedikit dengan Meria Susana (2011) yang menerapkan model inkuiri pada saat penelitiannya dapat meningkatkan berpikir kritis pada tema sejarah uang.

Selain proses pembelajaran dan nilai rata-rata kemampuan berpikir kritis siswa yang mengalami peningkatan pada pelaksanaan siklus III dalam kegiatan penelitian ini , nilai evaluasi siswa juga meningkat. Hal ini dapat dilihat dari nilai rata-rata hasil evaluasi siswa semakin meningkat tiap tindakan. Nilai rata-rata hasil evaluasi siswa terus mengalami peningktan. Hal tersebut dapat di lihat pada grafik di bawah ini: 


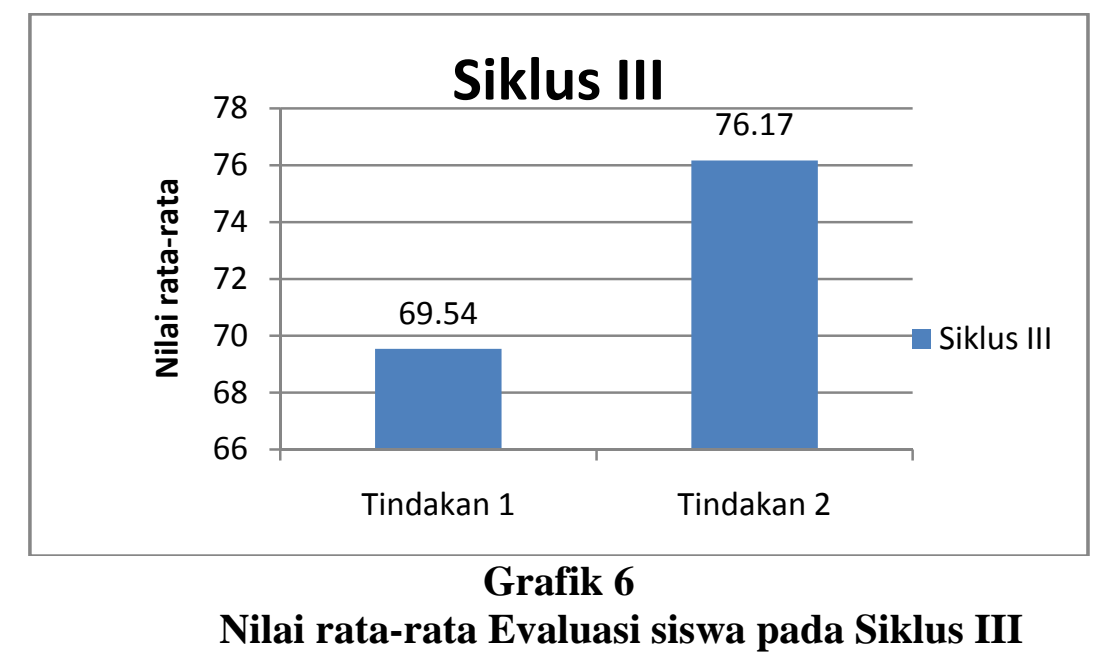

\section{E. SIMPULAN DAN SARAN}

1. Kesimpulan

a. Pembelajaran IPS dengan menggunakan model Inkuiri dapat meningkatkan kemampuan berpikir kritis siswa, kemampuan berpikir kritis pada diri siswa. Peneliti menggunakan model Inkuiri pada konsep Lingkungan alam dan buatan. Hal ini dapat dilihat dari perolehan nilai rata-rata proses berpikir kritis siswa persiklus. Siklus I nilai rata-rata 5, 33, siklus II nilai rata-rata 6, 16, dan siklus III nilai rata-rata 7, 56. Dari hasil perolehan nilai berpikir kritis menunjukkan bahwa pembelajaran dengan menggunakan model Inkuiri dengan Konsep Lingkungan alam dan Buatan dapat meningkatkan

b. Hasil belajar siswa dalam pembelajaran konsep Lingkungan alam dan Buatan dengan menggunakan model pembelajaran Inkuiri dari siklus ke siklus menunjukkan adanya peningkatan. Hal ini dapat di lihat dari perolehan nilai rata-rata individu dan kelompok. Nilai rata-rata siklus 1 yaitu: 56, 53, siswa yang memperoleh nilai diatas rata sebanyak 26 orang siswa, nilai dibawah rata-rata sebanyak 21 0rang siswa. Nilai rata-rata siklus II yaitu 62, 15, siswa yang memperoleh nilai diatas rata-rata sebanyak 34 orang, nilai dibawah rata sebanyak 13 orang. Nilai rata-rata siklus III yaitu 72, 85, siswa yang memperoleh nilai di atas rata-rata sebanyak 30 orang siswa, nilai dibawah rata sebanyak 17 orang. Sedangkan hasil evaluasi kelompok, sebagai berikut: siklus I dengan nilai rata-rata 64, 71, siklus II 68, 05, siklus III 79, 77.

2. Saran

a. Untuk merangsang timbulnya masalah-masalah dari siswa, guru harus memikirkan suatu kegiatan eksplorasi yang akan dilakukan oleh siswa agar siswa mempunyai gagasan untuk mengemukakan pendapat dan mengajukan pertanyaan terhadap materi yang akan di ajarkan.

b. Untuk menumbuhkan keberanian seluruh siswa dalam mengungkapkan masalah, guru harusmemberikan penguatan kepada siswa yang bertanya sehingga siswa lainnya termotivasi untuk bertanya.

c. Untuk meningkatkan hasil belajar siswa hendaknya guru memberikan soal evaluasi yang mudah dipahami dan dimengerti oleh siswa, sehingga dengan mudah siswa dapat mengerjakan soal yang diberikan. Penggunaan model 
pembelajaran yang tepat akan membuat siswa tertarik dan bersemangat untuk belajar. Rangsangan yang diberikansesuai guru terhadap siswa hendaknya berupa pertanyaan yang dikaitkan dengan kehidupan sehari-hari siswa dan yang sesuai dengan konsep awalyang telah diketahui sebelumnya sehingga hasil belajar akan semakin meningkat.

\section{DAFTAR PUSTAKA}

Arief Achmad, 2007, Memahami Berpikir Kritis, diambil dari http://researchengines.com/1007arief3.html; 13 April 2010; 20:23 wib.

Dahar, WR. (1996). teori-teori belajar.Jakarta: Erlangga

Departemen Pendidikan Nasional. (2006). Kurikulum 2006 Standar Kompetensi.

Djahiri, A. Kosasih (1995). Buku pedoman Guru Pengajaran IPS. Tempat dan penerbit tidak jelas

Hamalik Oemar. (2004). Proses Belajar Mengajar. Jakarta: Bumi Aksara

Heriawan Adang, Darmajari dan Senjaya Arip.(2012).Metode Pembelajaran, KajianTeorotis, Model, Pendekatan, Strategi dan Teknik Pembelajaran.Serang-banten: Perpustakaa Nasional.

Iskandar, M.Pd. (2011). penelitian Tindakan Kelas. Jakarta: Gaung Persada.

Ishack, S.U, dkk. (2005). Pendidikan IPS SD.Materi Pokok PGSD.jakarta: Universitas Terbuka.

MohommadAshori (2007), Penelitian Tindakan Kelas, Bandung: CV Wacana Prima

Negara Republik Indonesia. (2003). Undang-Undang Negara RI No.20 Tahun 2003. Tentang Sistem Pendidikan Nasional .Bandung: Fokus Media.

Rudy Gunawan, M.Pd. (2011). Pendidikan IPS .Bandung: Alfabeta

Rusman, M.Pd. (2011). Model-model Pembelajaran.Jakarta: Rajawali Pers.

SardimanA.M. (2007). Interaksi Belajar Mengajar. Jakarta: Raja Grafindo

SarlitoWirawan Sarwono, 2009, Berpikir Kritis Dan Benar, diambil dari http://www.ahmadheryawan.com/opini-media/sosial-politik/4246-berpikirkritis-dan-benar.pdf; 13 April; 2010; 21:11 wib.

Sanjana Wina, M.Pd. (2006). Strategi Pembelajaran Berorientasi Standar Proses Pendidikan. Jakarta: Prenada Media Group.

Sanjaya, Wina. Dr. (2008). Strategi Pembelajaran Berorientasi Standar Proses Pendidikan. Kencana Prenada Media Group. Jakarta

Sagala, S. (2003) konsep dan makna pembelajaran.BandungAlfabeta.

Sapriya, etal. (2006). Pembelajaran dan evaluasi hasil belajar IPS. Bandung: Tidak di terbitkan

Sapriya, M.Ed. (2009). Pendidikan IPS.Bandung: PT Remaja RosdakaryaOffset.

Suryani, N. (2008). Model Inkuiri untuk meningkatkan berpikir kritis siswa dalam pembelajaran IPSdiSD.Skripsi: Tidak diterbitkan.

Suryantin (2006). Pendekatan Inkuiri untuk meningkatkan aktivitas belajar siswa dalam pembeajaran IPS. Skripsi: Tidak diterbitkan.

Susana .M (2011). Model Inkuri untuk meningkatkan berpikir kritis siswa dalam pembelajaran IPS di sekolah dasar. 
Suarna, Al Muchtar. (2004) .Pengembangan Kemampuan Berpikir dan Nilai dalam Pendidikan Ilmu Sosial.Bandung: Disertasi Fakultas Pasca Sarjana IKIP Bandung.

Trianto, M.Pd. (2011).Panduan Lengkap Penelitian Kelas.Jakarta: Prestasi Pustaka.

Trianto, M.Pd. (2009).Mendesain Model Pembelajaran Inovatif-Progresif. Jakarta: Prenada Media Group.

Usman, Moh.Uzer. (2000). Menjadi Guru Profesional. Bandung Remaja Rosdakarya

Wiriaatmadja, R. (2005).Metode Penelitian Tindakan Kelas.Bandung: Ramaja Rosdakarya

http://id.shvoong.com/social-sciences/education/2231335-definisi-ips-dankarakteristiknya/\#ixzz28uFBshwH

http://www.edukasi.net/mol/mo_full.php?moid=134\&fname=bio_106_kb2_hal20. $\underline{\text { htm }}$

http://id.shvoong.com/social-sciences/education/2253878-ciri-ciri-dankarakteristik-pembelajaran/\#ixzz28ulqSTnK 